\title{
Teaching and teacher education in the time of COVID-19
}

\author{
Jeanne Allen, Leonie Rowan \& Parlo Singh
}

At the same time as we look towards happier and most positive futures, it would be unconscionable not to acknowledge in this issue of the journal the situation in which humankind now finds itself, and to consider the terrible toll that the COVID-19 pandemic is having on people's lives throughout the world. To those who have lost loved-ones, who have been struck down by the virus, who are without work or at risk of being so, who find themselves stranded in countries far from home, with borders closed, separated from families and friends, and who are suffering loss and anxiety in one or a number of a myriad of other ways - too many to mention-we extend our deepest sympathy and strongest compassion. And let's not forget the many Australians who are still rebuilding their lives after the devastating Summer fires, and who now have the COVID-19 world phenomenon to deal with.

Although it sounds trite to say that we are in this together, this just might generate one of the silver linings that emerges from the current crisis - a reconnection with those around us and a stronger sense of shared empathy and kindness for one another, as well as a greater appreciation for our beautiful planet. The fragility of life has become powerfully evident to us all.

As we write this, Australia, unlike many other countries, is not yet in a state of total lockdown. Most non-essential services have ceased and regulations to do with outdoor movement and physical distancing become stricter day by day. However, those in essential services, such as healthcare and education, continue to carry out their work, albeit in some changed circumstances and via different service delivery modes. These people have been, and are continuing to serve at the "front line" as the pandemic sweeps our nation. To them all, we owe a huge debt of gratitude.

Teachers and teacher educators are transitioning through a particularly uncertain time in terms of their professional lives and work. The rapid move to online modes of delivery in order to keep students engaged in learning - from early childhood through to the tertiary sector-has led to significantly intensified workloads for staff as they work to not only move teaching content and materials into the online space, but also become sufficiently adept in navigating the requisite software. The impact on staff and students is uneven-in some contexts, for example many universities, there are already established online and mixed modes of course delivery, such that the onus is now on building greater capacity through these avenues. In others, particularly many schools, the move to the online space is presenting considerable hardship as teachers struggle to adapt to what might well be the "new normal" for quite a period of time.

With regulations changing about every two days in this country, there is an abject lack of clarity in many instances about what the best and, to cite the Prime Minister Scott Morrison himself, most appropriate "Australian" action is to take. While Scott Morrison reiterates that the medical expert advice is that it is safe to send children to school, where does this leave teachers and other adults working in educational contexts? Has the practicality of enforcing the required physical distancing measures at the same time as teaching in regular classrooms actually been thought through? Similarly, in higher education - where many teaching spaces simply do not allow for people to maintain a $1.5 \mathrm{~m}$ distance from each other. Yet many 
campuses nevertheless remain open, in compliance with federal government regulations. However, it is beyond the scope of this editorial to dwell on policy critique, and so we will leave this type of commentary to others. Suffice to say that, when we look back on this period in time, when it is all over, there will be many lessons learned as to how our schools and universities are governed - and whose voices count in making the decisions that cannot but affect our lives.

Long-term, the ramifications of the COVID-19 pandemic on how we function, on what we prioritise and on what we let lapse in institutional settings might well prove to be significant. Take, for example, the emphasis on globalisation in the higher education arena. Apart from the economic advantages for many countries such as Australia, where education is one the country's largest exports (Dorn \& Schinke, 2018), there is also an ideological stance that conceptualises globalisation as highly beneficial in terms of free trade, increased capital and labour mobility, increased economies of scale and greater competition (Pettinger, 2017). A stance, which we hasten to add, is not shared by all (see, e.g., Saval, 2017). As nearly all countries close their borders in attempts to prevent the spread of the coronavirus, we are reminded of how, despite several decades of intensifying globalisation, nationhood is alive and well. Who belongs, and who doesn't, is underscored every day as countries call their citizens home and refuse entry to those from other lands. How this will impact on education, particularly higher education, in the long term is yet to be seen. The words of Greg Sheridan, foreign editor of the Australian, are notable in this regard:

Coronavirus is the hunter-killer of globalisation. The first reaction to this virus must be compassion and human solidarity. It is above all a health crisis. But it will have profound and lasting social, economic, political, cultural and geo-strategic consequences. ... And the first is this. COVID19 will transform, if not completely kill, globalisation as we have known it. (The Australian, 18 March 2020)

More immediately, it will be interesting to discover how online pedagogies serve the interests of teachers and learners and enable the high levels of student engagement and outcomes to which we aspire as teachers and teacher educators. Although there is an array of different software facilities and functionalities, one cannot help but wonder whether online teaching will spell a return to more traditional ways of teaching, and what the consequences of this might be, in terms of both teachers' and students' engagement. In 2019, Gert Biesta noted the irony in the fact that:

... some of the most popular technology-mediated forms of educationsuch as TED talks, MOOCs and the numerous professional and amateur instructional videos on YouTube - are all staged in traditional ways, with someone talking and explaining so that others can watch, listen and learn.

Will we be driven via the crisis in which we currently find ourselves to return to traditional ways of teaching, such as noted by Biesta? Or will new ways of teaching, of learning, of engaging with one another emerge and constitute the mainstream in the future? This, of course, remains to be seen. 
The six papers in this issue discuss, along different lines and in different ways, the working lives of teacher educators. Yongzhan Li examined the relationship between organisational justice, perceived supervisor support, and affective commitment among teachers in higher education in China and, in so doing, went someway in addressing a gap in the literature regarding the relationship among these three variables. Using structural equation modelling and bootstrap analysis, $\mathrm{Li}$ sampled 426 teachers from five Chinese universities to generate several significant results. First, the results show that organisational justice significantly influences perceived supervisor support and affective commitment; second, perceived supervisor support significantly influences affective commitment, and, third, perceived supervisor support partially mediates the effect of organisational justice on affective commitment.

Silvia Edling and John Liljestrand report on their analysis of the media's role in naming and framing the debate about teacher education in Sweden. Using content analysis, Edling and Liljestrand examined how articles published over two years in four major Swedish represented the challenges and strengths of teacher education and reported on the ensuing nature of teacher professionalism in that country. The findings of their analysis are concerning - and arguably mirror what one might expect to find in other countries - with the media underscoring the negative aspects of teacher education and raising questions about the levels of knowledge of teachers and student teachers, as well as behaviour management problems in the classroom. The authors note that, while there are instances of more nuanced reporting about teacher education, these tend to remain marginalised.

In their paper, "Fidelity of summative performance assessment in initial teacher education: The intersection of standardisation and authenticity," Australian researchers Lenore Adie and Claire Wyatt-Smith report on the Graduate Teacher Performance Assessment (GTPA), a validated final-year teaching performance assessment that began in 2019. As in other countries, such as the US, teacher performance assessments of this type constitute a highstakes, culminating assessment of beginning teacher competence. Throughout the implementation phases of the GTPA, the concept of assessment fidelity emerged as a significant research and practice issue, which motivated the authors to analyse a large corpus of recorded talk of experienced teacher educators collected during the 2017 trial of the GTPA. Their analysis drew on Gee's notion of 'identity' for examining situated meaning and Fairclough's concepts of discourse, sociocultural practice and materiality to demonstrate, among other findings, the complexity of the processes involved in working with the GTPA for teacher educators.

Michael Cavanagh and Alexis King approach the well-researched area of initial teacher education professional experience, yet in a novel way. Their focus is on the experiences of primary pre-service teachers who engage in a peer-group mentoring (PGM) program during their professional experience placement. Using coding analysis to analyse participants' responses to a questionnaire and interviews, Cavanagh and King generated themes including the role of the professional standards, the practical nature of the activities undertaken, increased confidence to teach, and feelings of belonging and being supported. Interestingly, the participants in the PGM did not make links between theory and practice in the sessions, which prompted the authors to put forward ways in which Australian pre-service teachers might benefit from a PGM program that has been shown to be successful in the Finnish context. 
The title of Margie Appel's paper, "Performativity and the demise of the teaching profession: the need for rebalancing in Australia" signals the concerns that Appel holds about teachers' work and teacher professionalism in Australia. Identifying three significant elements of teachers' professionalism as knowledge, autonomy and responsibility, Appel argues that the current performance and accountability culture within which teachers function has eroded their autonomy, stifled their creativity and led to a breach of trust. Appel's claims emerge from a literature review, focusing specifically on teachers' experiences in the era of standardisation, the effect of performativity on teacher professionalism and the implications for the future. Quite presciently, it would seem, Appel makes the claim that, given the rapid changes taking place in schools through the impact of globalisation, it is imperative that schools have the ability to be flexible and educate students to work in an unknown future.

The final paper in this issue could not be timelier, given the impact that COVID-19 is having on delivery modes and methods of learning and teaching: Australians Janet Dyment and Jill Downing provide a systematic literature review (SLR) of online learning in initial teacher education (ITE). Once quite a controversial topic, particularly in some areas such as the Arts (see, e.g., Allen, Wright, \& Innes, 2014), online learning is now commonplace in teacher education. Using a robust SLR protocol based primarily on the 2012 work of Gough, Oliver and Thomas, as well as that of Cooper (2017), Dyment and Downing generated five themes from across the 492 refereed articles included in the review. Accordingly, they argue for a more systematic, shared and strategic approach to building the knowledge base on online learning in teacher education, and issue a clarion call for a more strategic, cohesive, and collaborative approach to researching online ITE. This will require strong leadership, coordination, and collaboration, if researchers are to move beyond the often silo-ed and sometimes narrowly-focused research conducted into the benefits and challenges of online learning and teaching in ITE. In 2020 and beyond, one imagines there will be ample opportunities for researchers to respond to this call.

Allen, J. M., Wright, S., \& Innes, M. (2014). Pre-service visual art teachers' perceptions of assessment in online learning. Australian Journal of Teacher Education, 39(9). http://ro.ecu.edu.au/ajte/vol39/iss9/1

Biesta, G. (2019). Teaching for the possibility of being taught: World-centred education in an age of learning. English E-Journal of the Philosophy of Education, 4, 55-69.

Dorn, F., \& Schinke, C. (2018). Top income shares in OECD countries: The role of government ideology and globalisation. The World Economy, 41(9), 2491-2527.

Pettinger, T. (2017). Cracking Economics. London, UK: Octopus Publishing Group.

Saval, N. (2017, July 14). Globalisation: the rise and fall of an idea that swept the world. The Guardian. https://www.theguardian.com/world/2017/jul/14/globalisation-the-riseand-fall-of-an-idea-that-swept-the-world

Sheridan, G. (2020, March 18). Why this COVID-19 pandemic will kill globalisation. The Australian. https://www.theaustralian.com.au/commentary/personality-of-nationalitycounts/news-story/784d8e0c22f7f9a82be69404edb6beee 